\title{
PERAN ORANG TUA SEBAGAI PEMBENTUK EMOSIONAL SOSIAL ANAK
}

\author{
Nurul Lailatul Khusniyah ${ }^{1}$ \\ Universitas Islam Negeri Mataram, Indonesia \\ nurullaila@,uinmataram.ac.id
}

\begin{abstract}
Absrak: Tujuan utama dari penelitian ini adalah untuk mengetahui lebih mendalam tentang pengaruh peran orang tua terhadap pembentukan sosial emosi anak-anak usia dini. Partisipan penelitian ini adalah para orang tua (ayah dan ibu) serta anak-anak yang duduk di bangku sekolah taman kanakkanak di Kecamatan Ampenan. Metode penelitian ini adalah deskriptif kualitatif, yang meneliti tentang fenomena sosial. Proses pengumpulan data menggunakan angket, observasi, dan wawancara. Teknik analisis data menggunakan credibility, transferability, dependability, danconformability serta uji pakar psikologi anak. Hasil analisis menunjukkan bahwa ada pengaruh yang sangat signifikan peran orang tua terhadap pembentukan kepribadian dan sosial emosional anak-anak, yang berdampak pada kesuksesan dan kepribadian anak di masa dewasa.
\end{abstract}

Key words: Anak, Orang Tua, Peran, Sosial Emosi

\section{PENDAHULUAN}

Setiap anak dilahirkan memiliki kemampuan ataupun potensi yang sudah baik dan harus diwujudkan serta dikembangkan, sehingga bakat-bakat yang dimiliki anak akan muncul untuk membantu keberlangsungan hidup di masa dewasa. Hal ini dapat diwujudkan melalui proses pembentukan emosi sosial dan spiritual yang baik. Dengan demikian, para anak-anak akan mampu mengembangkan potensi yang dimilikinya dengan maksimal. oleh karena itu, orang tua sebagai kunci utama pendidik utama bagi anak wajib membangun lingkungan yang baik selama proses pendidikan berlangsung.

1 Dosen pada Fakultas Tarbiyah dan Ilmu Keguruan UIN Mataram 
Orang tua khususnya seorang ibu memiliki peranan besar terhadap pembentukan pola emosinal sosial anak dan pola pendidikan anak di masa depan. Iklim psikologis dan khususnya spesifik hubungan keluarga memainkan peran penting dalam membentuk kepribadian seorang anak. Selain itu, interelasi orangtua dalam keluarga, hubungan orangtua-anak dalam keluarga terus menggunakan pengaruhnya selama masa kanak-kanak dan kemudian kehidupan dewasa seseorang. ${ }^{2}$ Oleh karena itu, menurut mereka, aspek yang paling menarik dalam studi peran interaksi orangtua-anak adalah peran orangtua. Vasilyeva dan Schernakov menyebutkan peran fungsional orang tua sebagai fungsi sosial anggota keluarga terhadap seorang anak, yang sesuai dengan kehidupan keluarga, kode perilaku yang diadopsi keluarga, tradisi, dan hubungan interpersonal yang telah ditetapkan. Menurut Vasilyeva dikatakan bahwa struktur "ibu / ayah" memiliki 20 peran orangtua fungsional, menciptakan teknik untuk menentukan struktur peran interaksi orangtua-anak, yang telah digunakan dalam penelitiannya.

Dari paparan tersebut dapat diketahui bahwa emosional sosial anak akan terbentuk dari hasil interaksi orang tua dan anak serta pola asuh orang tua. Namun, di Indonesia, hal tersebut masih menimbulkan permasalahan. Banyak para orang tua yang belum memahami bagaimana emosional sosial anak. Sehingga di sekolahsekolah seringkali terjadi kasus bullying ataupun kekerasan terhadap sesama teman, sampai anak-anak mengalami proses hokum. Dari kasus-kasus yang terjadi terhadap anak di sekolah ataupun lingkungan masyarakat telah menjadi pekerjaan rumah bagi para orang tua, khususnya ibu yang lebih banyak bersama para orang tua untuk membenahi pola asuh. Hal ini bisa berdampak pada pembentukan emosional sosial yang baik. Dengan demikian, si anak akan memahami pola aturan dan hukuman dari setiap tindakan yang dilakukan. Jadi dapat disimpulkan bahwa potensi sosial emosi anak yang stabil dari kecil akan berlanjut sampai dewasa. Seperti yang dikatakan oleh Abe \& Izard bahwa kompetensi emosional dan sosial menyajikan pola yang relatif stabil sepanjang waktu, dari usia prasekolah hingga remaja. ${ }^{3}$ Hurlock mengutarakan bahwa perkembangan sosial merupakan perolehan kemampuan berperilaku yang sesuai dengan tuntutan sosial. "Sosialisasi adalah kemampuan bertingkah laku sesuai dengan norma, nilai atau harapan sosial". ${ }^{4}$

2 E. N.Vasilyeva \& A.V, Shlmchlmerbakov, Parental Roles and Types of Parentings as Determinants of a Preschlmooler's Emotional and Personal Well-being. Procedia - Social and Behlmavioral Sciences, 233, 2016, hlm.144-149. hlmttps://doi.org/10.1016/J.SBSPRO.2016.10.172

3 J. A.Abe\& C. E.Izard, A longitudinal study of emotion expression and personality relations in early development. Journal of Personality and Social Psychlmology, 77,1999,hlm..566-577.

4 E.B.HLMurlock,Chlmiled Development. $6^{\text {thlm }}$ Ed. (Tokyo: Mc. Graw HLMill. Inc., International Studend Ed, 1978), hlm.250 
Dari paparan tersebut perkembangan emosi sosial anak sangat ditentukan oleh interaksi antara orang tua dan anak. Pengajaran norma-norma dan aturan-aturan sosial, moral kepada anak-anak harus dimulai dari usia 0 tahun. Seperti studi yang telah dilakukan di Rusia tentang kekhasan psikologis anak-anak prasekolahmenyimpulkan bahwa garis utama dalam perkembangan mental anak adalah perkembangan emosional. ${ }^{5}$ Artinya bahwa komponen-komponen perkembangan emosi antara lain; membedakan emosi, memahami emosi, mengelola emosi, memfasilitasi proses berpikir; kecerdasan, serta hubungan yang erat antara kecerdasan emosional dan umum.

Banyak penelitian yang telah dilakukan tentang hubungan orang tua dengan pementukan emosi sosial anak, seperti Karabanovamembuktikan bahwa seorang dewasa menunjukkan dunia luar (lingkungan) kepada seorang anak, dan, di atas segalanya, lingkungan bertindak sebagai dunia hubungan interpersonal manusia, dunia manusia dan didasarkan pada emosi dan perasaan. ${ }^{6}$ Hal ini sama seperti ysng dilakukan Vinnikott ${ }^{7}$ dan Horny ${ }^{8}$. Psikolog Rusia, Lisina ${ }^{9}$ telah menunjukkan bahwa hubungan orang tua-anak melalui pengembangan posisi aktif terhadap orang tuanya telah menentukan sifat interaksi anak dengan orang dewasa dan teman sebaya, yang dimodifikasi dan menjadi lebih rumit sepanjang masa kanak-kanaknya. Ini memberikan alasan bahwa perkembangan emosional anak harus dianggap sebagai titik utama di sekitarnyakegiatan bersama orang tua dan taman kanak-kanak harus dibangun. Kegiatan bersama orang tua, psikolog dan pendidik dalam memodelkan lintasan perkembangan individu anak, berdasarkan usia anak dan kekhususan individu dan dengan mempertimbangkan keinginan orangtuanya dan peluang dari taman kanak-kanak, harus dianggap sebagai isi dari kerja sama.Top of Form

Berdasarkan paparan tersebut, kajian ini bertujuan untuk menjawab permasalahan yaitu; apakah peran orang tua mempengaruhi pola pembentukan emosi sosial anak-anak? Dari permasalahan tersebut kajian ini diharapkan mampu memberikan pemahaman baru terhadap para orang tua khususnya para ibu bahwa

5 G.M.Bresly, Emotcionalnie osobennosti Formirovaniia Lichlmnosti v Detstve: Norma I Otklonenie \{Emotional peculiarities of roaming thlme individual in chlmildhlmood: norm and deviation\}. M:Pedagogika, 2010, hlm.246. \{in Russian\}

6 O.A.Karabanova,Psikhlmoliaa semeinikhlm otnoshlmenii I osnovy semeinigo konsyltirovaniia [Psychlmology of HLMuman Intelligence ( $2^{\text {nd }}$ ed). (New York: Cambridge, 2005)

7 B.Volling, McElwain, N., Notaro, P., \& HLMerrera, C, Parents' emotional availability and infant emotional competence: Predictors of parent-infant attachlmment and emerging self-regulation. Journal of family psychlmology, 16, 2002, hlm. 447-465.

8 K. HLMorny,Nevrotichlmeskaia lichlmnost nashlmego vremeni. Samoanaliz. [Neurotic personality of our time. Introspection.]. M: Progress, 2008

9 M.I.Lisina,Formirovanie lichlmnosti rebenka $v$ obshlmchlmenii [Forming personality of a chlmild in communication]. St. Petesburg: Piter, 2009. 
emosi sosial yang telah terbentuk dari semenjak masa usia dini akan tersimpan dalam alam bawah sadar. Oleh karena itu, seorang ibu harus hati-hati dalam setiap tindakan agar menjadi teladan yang baik bagi anak. Selain itu, kajian ini juga menjadi sumbangsih bagi ilmu pengetahuan khususnya dalam pengembangan keilmuan yang berhubungan dengan pengkajian peran orang tua dalam mendidik anak-anak.

\section{Perkembangan Emosi Sosial Anak}

Proses pengasuhan seorang anak seringkali diasumsikan oleh kebanyakan orang merujuk pada mengganti popok, waktu makan yang berantakan, dan mengejar anak yang menjerita atau anak-anak yang bermain begitu aktif. Tetapi pengasuhan anak jauh melampaui persyaratan untuk memenuhi kebutuhan dasar kelangsungan hidup anak, dan orang tua memiliki pengaruh signifikan terhadap bagaimana anakanak berubah, termasuk kepribadian mereka, perkembangan emosi, dan kebiasaan perilaku, serta sejumlah faktor lainnya. Penting bagi perkembangan keseluruhan anak-anak bahwa orang tua cukup hadir untuk mendukung mereka, dan dukungan ini menumbuhkan kepercayaan diri dan pertumbuhan di banyak bidang.

Terkadang, perhatian terhadap fisik tidak cukup, karena perkembangan jiwa anak menjadi bagian utama dalam penentuan kehidupannya di masa depan. Orangtua yang mungkin berada di dekatnya tetapi tidak diinvestasikan secara emosional atau responsif cenderung membesarkan anak-anak yang lebih tertekan dan kurang terlibat dengan permainan atau kegiatan mereka. Sebuah penelitian yang menyelidiki hubungan antara investasi orang tua dan kompetensi anak-anak menunjukkan bahwa keterlibatan emosional orang tua benar-benar penting dan mempengaruhi hasil dari kompetensi dan regulasi emosional anak mereka. ${ }^{10}$ Orangtua harus mengingat hal ini ketika mempertimbangkan kualitas waktu yang mereka habiskan bersama anak-anak mereka, karena jika mereka tidak cukup menginvestasikan waktu dan komitmen mereka untuk menuangkan emosi ke dalam anak mereka, anak akan berjuang untuk belajar bagaimana mengatur emosi dan berinteraksi dengan orang lain dengan tepat.

Sroufe" menegaskan bahwa, "Variasi kualitas hubungan semacam itu bukanlah refleksi dari ciri-ciri genetis bayi tetapi dari sejarah interaksi dengan orang tua”. Ini

10 B. Volling, McElwain, N., Notaro, P., \& HLMerrera, C. Parents' emotional availability and infant emotional competence: Predictors of parent-infant attachlmment and emerging self-regulation. Journal of family psychlmology, 16, 2002, hlm. 447-465.

11 L. A.Sroufe, From infant attachlmment to promotion of adolescent autonomy: Prospective, longitudinal data on thlme role of parents in development. In J. G. Borkowski, S. L. Ramey \& M. Bristol-Power (Eds.), Parenting and thlme Chlmild's World: Influences on Academic, Intellectual, and Social-emotional Development. Psychlmology Press. 2001 
menunjukkan bahwa gaya kelekatan tidak lahir tetapi didorong oleh bagaimana orang tua berinteraksi dengan bayi mereka sejak lahir. Studi kelekatan longitudinal menunjukkan bahwa anak-anak dengan keterikatan kecemasan cenderung terganggu secara emosional dan memiliki harga diri yang rendah. Dari pernyataan tersebut dapat diketahui bahwa bentuk keterikatan secara emosional antara orang tua dan anak memiliki dampak jangka panjang sampai anak tersebut tumbuh dewasa. Mereka akan berkembang sesuai dengan perkembangan emosional yangtelah tertanam dalam diri mereka semenjak anak-anak. Jika semenjak anak-anak mengalami perkembangan emosi sosial yang kurang baik, maka akan berdampak pada sikap dan perilaku anak di masa dewasa tidak baik pula.

Salah satu faktor penting dalam perkembangan emosi anak adalah bagaimana pengasuh yang hangat, dan penelitian telah dilakukan untuk menemukan efek dari ibu yang depresi pada perkembangan emosional anak-anak. Ibu yang depresi memiliki pikiran, sikap, dan perilaku maladaptif. Hal ini bersama dengan berada di lingkungan yang sama stres sebagai ibu, menempatkan anak pada risiko mengembangkan masalah emosional sendiri. Kenyataan bahwa ibu yang depresi cenderung bersikap tidak peduli terhadap anak-anak mereka, menempatkan mereka dalam situasi yang kurang sosial, dan umumnya memberikan lebih sedikit stimulasi untuk anak-anak mereka, menempatkan anak-anak pada posisi yang kurang menguntungkan untuk mencapai perkembangan emosional yang normal.

Aspek kunci dari perkembangan emosi pada anak-anak adalah belajar bagaimana mengatur emosi. Anak-anak melihat bagaimana orang tua mereka menampilkan emosi dan berinteraksi dengan orang lain, dan mereka meniru apa yang mereka lihat pada orang tua mereka dan yang telah dilakukan untuk mengatur emosi. ${ }^{12}$ Temperamen seorang anak juga memainkan peran dalam regulasi emosi mereka, dipandu oleh gaya pengasuhan yang mereka terima. Sebagai contoh, anak-anak lebih rentan terhadap emosi negatif atau episode kemarahan sangat dipengaruhi oleh pengasuhan bermusuhan dan lalai, sering mengarah ke masalah perilaku bahkan lebih. Temperamen yang sulit dapat menjadi masalah dua arah yang membangkitkan lebih banyak emosi negatif dari orang tua jika tidak dipantau. Orangtua harus menyadari bahwa tidak hanya emosi dan gaya pengasuhan mereka sendiri mempengaruhi hasil emosional anak-anak mereka, tetapi jika mereka tidak menyadari bagaimana emosi anak-anak mereka mempengaruhi mereka, mereka dapat jatuh ke dalam spiral orangtua yang tidak efektif dan acuh tak acuh yang selanjutnya berkontribusi perilaku negatif dari anak-anak.

12 A. Shlmeffield,Morris,Silk, J. S., Steinberg, L., Myers, S. S., \& Robinson, L. R. Thlme role of thlme family context in thlme development of emotional regulation.Social Development, 16(2), 2007, hlm. 361-388. 
Lebih jauh lagi, bagaimana orang tua mengatasi emosi anak-anak mereka dan menanggapi mereka mempengaruhi bagaimana ekspresifnya perasaan anak-anak itu. Bereaksi dengan kritik atau menolak kesedihan atau kemarahan seorang anak mengkomunikasikan bahwa emosi mereka tidak valid atau tidak tepat, yang dapat menyebabkan anak-anak menjadi lebih rentan terhadap emosi negatif dan kurang mampu mengatasi stres. ${ }^{13}$ Sebaliknya, membimbing emosi anak-anak dan membantu mereka menemukan cara untuk mengekspresikan diri mereka dengan cara yang sehat membantu mereka terus mengatur tanggapan mereka terhadap tantangan dan bahkan membantu kompetensi akademis dan sosial mereka. Pelatihan emosi semacam ini sangat membantu dalam mengurangi perilaku masalah di masa depan pada anak-anak.

Vygotsky $^{14}$ menjelaskan bahwa bentuk-bentuk aktivitas mental berasal dari konteks sosial dan budaya dimana anak-anak berinteraksi dengan orang lain. Studi lain meneliti bahwa bentuk keterampilan sosial untuk anak-anak prasekolah, antara lain, asuh dan tanggaphubungan interpersonal dengan anak-anak lain secara memuaskan, tidak suka bertengkar, tidak egois, berbagi kue dan mainan. Dengan demikian keterampilan sosial anak perlu dikontrol karena akan membekali mereka untuk memasuki kehidupan sosial yang lebih luas. Lingkungan sosial meliputi lingkungan rumah terutama di sekolah dasar yang akan segera masuk dan terus menerus sampai ke lingkungan yang lebih luas, yaitu masyarakat umum. Masalah sosial taman dapat diidentifikasi dari berbagai perilaku yang terungkap anak-anak, termasuk anak-anak selalu ingin untuk menjadi egois, agresif, marah, setiap keinginan harus diikuti, menentang bahkan menarik diri dari lingkungan mereka dan tidak mau bergaul dengan teman-temannya.

Pada keterampilan sosial itu menjadi masalah krusial sehingga dapat dibangun dan dikembangkan kemampuan untuk bersosialisasi pada individu sejak dini. ${ }^{15}$ Pentingnya konteks sosial untuk proses belajar anak dan pengalaman interaksi sosial sangat penting dalam mengembangkan kemampuan anak untuk berpikir. Vygotsky juga menjelaskan bahwa bentuk aktivitas mental berasal dari konteks sosial dan budaya di mana anak-anak berinteraksi sehingga memahami perkembangananak-anak, orang dewasa diminta untuk memahami hubungan sosial yang terjadi di lingkungan

13 R. Siegler, DeLoachlme, J., \& Eisenberg, N. HLMow chlmildren develop. (3rd ed.).( New York: Worthlm Publishlmers, 2011)

14 L. S.Vygotski, Learning and mental development at schlmool age (J. Simon, Trans.). In B. Simon \& J. Simon (Eds.), Educational psychlmology in thlme U.S.S.R. (pp. 21-34). (London: Routledge \& Kegan Paul, 1963).

15 Moeslichlmatun, Metode Pengajaran di Taman Kanak-Kanak. (Jakarta : Rineka Cipta, 1999) 
di mana anak-anak berkumpul. ${ }^{16}$ Ada beberapa faktor yang dapat mempengaruhi keterampilan sosial anak, yaitu, jenis kelamin, usia dan tahap perkembangan serta lingkungan. Keterampilan sosial yang dikembangkan melalui proses pembelajaran oleh individu dalam interaksi dengan lingkungan orang tua dan lingkungan anak-anak dapat mengoptimalkan perannya saat berinteraksi dengan anak-anak. Ini disebabkan karena kepekaan sosial anak mulai dari keluarga kemudian mengalami transisi ke lingkungan sekolah.

Pendidikan masa kanak-kanak awal harus mencakup seluruh proses stimulasi sosial interaksi dan tidak terbatas pada proses pembelajaran yang berlangsung dilembaga pendidikan yang hanya memprioritaskan aspek kognitif untuk perkembangan anak. Ini akan menunjukkan bahwa pendidikan anak usia dini dapat terjadi setiap saat serta intraksi manusia yang terjadi dalam keluarga, teman sebaya, dan hubungan sosial yang sesuai dengan kondisi perkembangan anak usia dini. ${ }^{17}$ Ketika anak menginjak tahap prasekolah, perkembangan anak yang berada dalam kemampuan untuk mengidentifikasi duniadi luar dirinya sendiri, kesiapan untuk berbagi dan mengurangi ketergantungan pada orang dewasa untuk memberikan bimbingan dan memenuhi kebutuhan mereka untuk persahabatan dan kemudian anak-anak siap untuk terhubung satu sama lain. Di satu sisi selama masa kanak-kanak, orang tua tetap menjadi agen sosialisasi yang paling penting sementara di sisi lain anak-anak prasekolah membutuhkan persahabatan dan membuat setiap upaya untuk memenuhi kebutuhan mereka. ${ }^{18}$ Efek stimulasi menyusui dan psikososial dari perkembangan sosio-emosional anak balita dipengaruhi oleh posisi ibu bekerja dan tidak bekerja. Hasil penelitian menunjukkan bahwa stimulasi psikososial menjadi salah satu faktor dominan yang mempengaruhi perkembangan sosio-emosional anak. Selain itu, perkembangan emosi anak juga dipengaruhi oleh usia anak. ${ }^{19}$

Berdasarkan paparan tersebut dapat dipahami bahwa perkembangan emosi sosial anak dipengaruhi oleh gaya pengasuhan atau pean orang tua dalam merawat dan memberikan pendidikan setiap harinya. Keputusan pengasuhan mempengaruhi bagaimana anak-anak berubah secara fisik, sosial, dan emosional, tetapi pula tidak

16 L. Berk, Chlmild development (4thlm ed.).Boston: Allyn \& BaconBerk, L.E. (2004). Awakening Chlmildren's Minds: HLMow Parents and Teachlmers Can Make a Difference. (Oxford University Press, 1997)

17 Saroinsong, Wulan Patria \& Cosmas Poluakan. Positive Contribution of Parenting and Socio -emotional Developmentin Chlmildren's Social Skills. International Journal of HLMumanities and Social Scienc 7(4),2017, hlm.124-127

18 Cohlmen, D.HLM. \& Rudolphlm, M. (1977). Kindergarten and early schlmooling. New Jersey: Prentice-HLMall Inc

19 Nuraeni,Pengaruhlm Pola Asuhlm Orang Tua Terhlmadap Pembentukan Kepribadian Anak Taman Kanak-Kanak, Tugas Akhlmir Universitas Negeri Semarang, 2016, On line: hlmttp://digilib.unnes.ac.id/gsdl/ collect/skripsi.1/tmp/2383.hlmtml (Accessed 25 Novermber 2018). 
berarti orang tua tidak harus terobsesi pada proses penentuan langkah-langkah tertentu dalam mendidik anak-anak. Jadi, tidak ada formula baku atau khusus yang sempurna untuk memodelkan perilaku anak-anak. Namun yang menjadi penting adalah orang tua harus membangun emosi sosial anak dengan baik sesuai dengan ajaran agama yang dianut, norma sosial, etika, adat istiadat, hokum ataupun aturan sosial masyarakat yang berlaku.

\section{Gaya Pengasuhan Ibu dan Ayah (Orang Tua) Terhadap Anak}

Hasil penyebaran angket dipeorleh simpulan bahwa secara keseluruhan gaya pengasuhan ibu dan ayah (orang tua) terhadap anak memberikan pengaruh besar terhadap pembentukan emosi sosial anak-anak, seperti tergambar pada tabel dan grafik persentase berikut ini.

Tabel 1. Persentase hasil penyebaran angket tentang pola asuh dan pengaruh orang tua terhadap anak

\begin{tabular}{|l|c|c|c|c|c|c|c|c|c|c|}
\hline \multirow{2}{*}{$\begin{array}{l}\text { Indikator } \\
\text { pembentuk } \\
\text { emosi sosial }\end{array}$} & \multicolumn{9}{|c|}{ Ibuis pengasuhan dan peran orang tua } \\
\cline { 2 - 11 } & 1 & $\mathbf{2}$ & $\mathbf{3}$ & $\mathbf{4}$ & $\mathbf{5}$ & $\mathbf{1}$ & $\mathbf{2}$ & $\mathbf{3}$ & $\mathbf{4}$ & $\mathbf{5}$ \\
\hline Kecemasan & $86,7 \%$ & $93,3 \%$ & $100 \%$ & $83,3 \%$ & $83,3 \%$ & $80 \%$ & $86,7 \%$ & $86,7 \%$ & $100 \%$ & $83,3 \%$ \\
\hline Self-esteem & $100 \%$ & $100 \%$ & $90 \%$ & $83,3 \%$ & $83,3 \%$ & $93,3 \%$ & $93,3 \%$ & $83,3 \%$ & $83,3 \%$ & $100 \%$ \\
\hline
\end{tabular}

Keterangan;

1. Perilaku penolakan

2. Kerjasama

3. Pola Komunikasi

4. Pola sosialisasi sosial

5. Kepribadian positif

Pada persentase tersebut dapat disimpulkan bahwa hasil angket dari para ayah memiliki prosentase lebih kecil dari ibu. Namun, secara keseluruhan persentase menunjukkan bahwa tingkat kecemasan dan harga diri baik dari orang tua maupun anak-anak memiliki konsep yang sama. Artinya bahwa indikator pembentukan sosial emosi anak dipengaruhi oleh kondisi emosi sosial yang dimiliki oleh setiap orang tua. Berikut ini hasil rata-rata dari setiap aspek yang muncul pada setiap indikator pengaruh emosi sosial anak. 


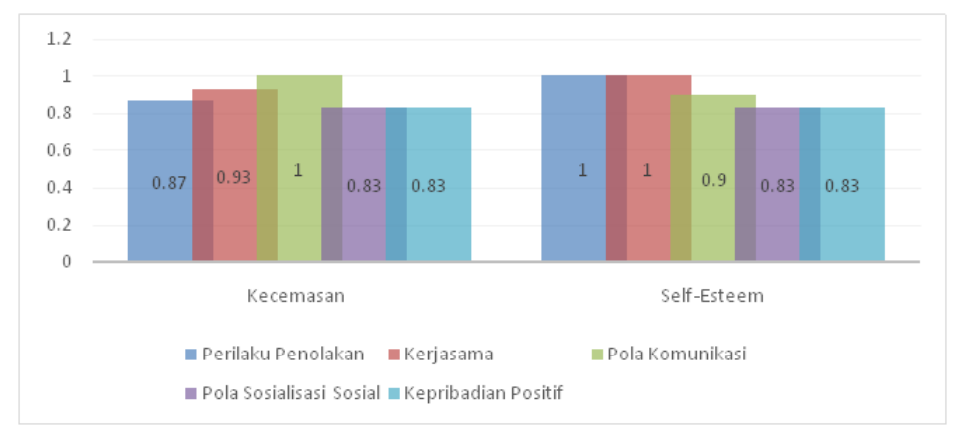

Grafik 1. Rata-rata Indikator Pengaruh Sosial Emosi Anak-anak dari Ibu

Hasil penyebaran angket kepada ibu menunjukkan bahwa nilai rata-rata hasil analisis terhadap pengaruh aspek pengembangan sosial emosi anak-anak yang berasal dari ibu sangat besar. Hal ini disebabkan karena ibu selalu berada di sisi anak-anak. Sedangkan hasil dari sebaran angket kepada ayah ditunjukkan pada grafik di bawah ini.

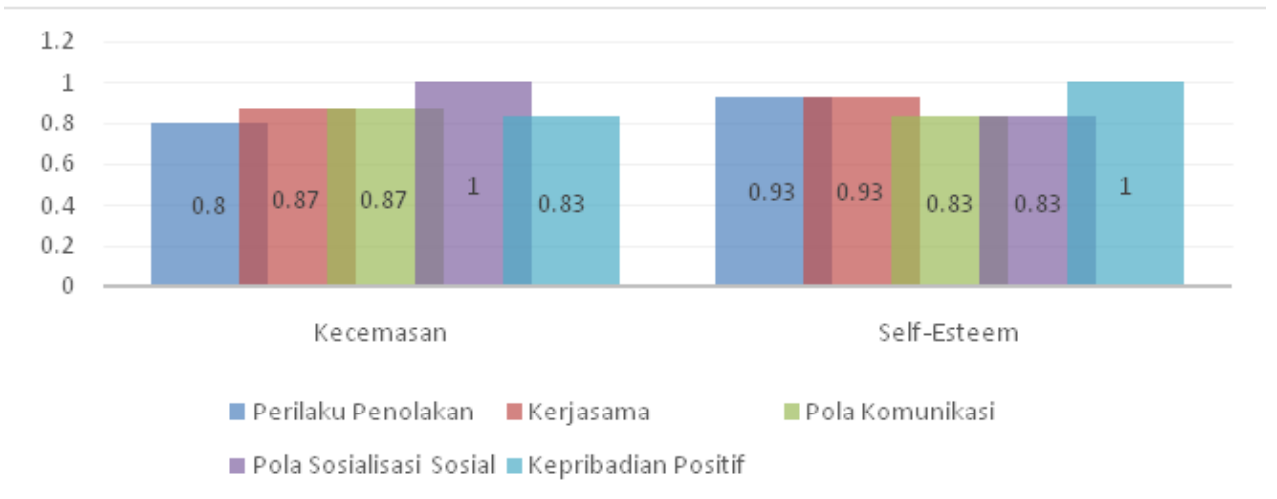

Grafik 2. Rata-rata Indikator Pengaruh Sosial Emosi Anak-anak dari Ayah

Dari kedua paparan grafik dan tabel di atas, disimpulkan bahwa peran orang tua baik ayah maupun ibu memiliki pengaruh yang sangat besar terhadap pembentukan kepribadian anak. Hal ini dipengaruh oleh sebagian besar dari pengaruh emosi sosial ayah dan ibu yang telah ditunjukkan kepada anak-anak. Berikut nilai rata-rata dari setiap indikator. 


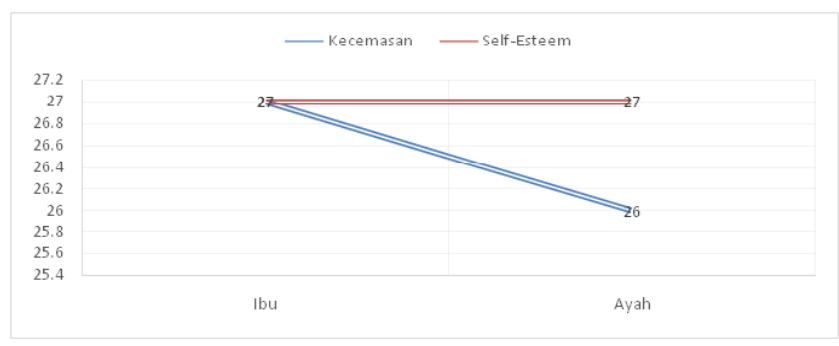

Grafik 3. Nilai Rata-rata Hubungan Antara Gaya Pengasuhan Ibu dan Ayah

Dari paparan tabel dan grafik di atas diismpulkan bahwa ibu memiliki persentase tertinggi pada semua aspek dari indikator kecemasan dan self-esteem. Perilaku penolakan orang tua terhadap keinginan anak menjadi sangat besar bagi perilaku kemarahan anak. Sikap kerjasama yang ditunjukkan orang tua mempengaruhi sikap kerjasama anak dengan teman-temannya di sekolah atau lingkungan luar rumah. Pola komunikasi yang baik dari orang tua menjadi teladan bagi anak dalam menuturkan kata dan kalimat yang baik dan sopan. Pola sosialisasi sosial menjadi proses bimbingan yang besar terhadap pola bersosialisasi anak di lingkungan masyarakat. Sedangkan kepribadian positif orang tua bisa menjadikan anak yang selalu berpikir positif dan semangat. Dari hasil pencapaian nilai rata-rata diketahui bahwa baik ibu maupun ayah memiliki nilai rata-rata sama besar untuk kedua indikator yang mempengaruhi perkembangan emosional sosial anak. Dengan demikian dapat disimpulkan bahwa ada korelasi positif antara jenis sikap ibu dan ayah terhadap anak-anak. Ketika ibu memperlakukan anak dengan sikap lamban, tidak mampu, mengabaikan minat, hobi, pikiran dan perasaannya, maka tingkat kecemasannya meningkat.

Perilaku penolakan merupakan bagian dari perilaku tiruan yang bisa terbentuk anak melalui sikap yang ditunjukkan oleh para orang tua. Sedangkan aspek kerjasama seringkali dianggap kurang signifikan yang ada dalam praktek gaya pengasuhan orang tua. Kerjasama berdampak proses interaksi yang saling membantu diantara para anakanak. Sehingga anak-anak memiliki rasa tanggung jawab yang telah memunculkan kemmpuan anak-anak untuk berkomunikasi dengan baik.

Penelitian yang telah dilakukan Zakharova \& Silakova menunjukkan menunjukkan bahwa hubungan orangtua-anak adalah subsistem keluarga khusus, yang merupakanpenentu paling penting dari kedua perkembangan mental dan emosional anak dan prosessosialisasi. Jenis hubungan lain yang ada di taman kanakkanak juga penting dalam perkembangan emosional anak-anak. Karakteristik utama dari sistem hubungan orangtua-anak adalah cinta yang menentukan kredibilitas 
kepada seorang anak, kesenangan dan kesenangan berkomunikasi dengan dia, keinginan untuk perlindungan dan keamanan, penerimaan dan perhatian tanpa syarat, dan sikap holistik. Karakteristik utama dalam sistem hubungan dengan seorang anak di taman kanak-kanak adalah saling pengertian dan interaksi satu sama lain, dengan mempertimbangkan karakteristik dan minat anak-anak lain.

Oleh karena itu para orang tua dalam memainkan peran harus membangun proses komunikasi yang baik dan dapat dipahami oleh anak-anak. Karena jika hal tersebut terjadi salah pemahaman maka kesalahan tersebut akan tertanam di alam bawah sadar anak sampai dewasa, yang pada akhirnya akan muncul dan digunakan pada waktu tertentu. Hal ini telah dibuktikan pula dalam penelitian. ${ }^{20}$ Dalam penelitiannya diketahui bahwa kesalahan mengasuh olehibu (perlindungan berlebihan, gratifikasi keinginan, sanksi berlebihan, kurang percaya diridalam kemampuan seseorang untuk membesarkan anak, fobia kehilangan anak, dorongan infantilisme) dan kesalahan ayah (perlindungan berlebihan, kebutuhan yang tidak mencukupi, perasaan orang tua yang belum berkembang, preferensi sifat laki-laki pada seorang anak) menghancurkan keterikatan positif dalam keluarga, serta hubungan sistemik multipersonal antara anak-anak dan dunia sekitarnya dan hubungan harmonis antara orang tua dan anakanak. Kesalahan pengasuhan memunculkan kesulitan komunikasi dasar, terkait konten, instrumental, dan reflektif; menentukan bentuk perilaku anak-anak nonkonstruktif dalam situasi komunikatif (agresi, protes, perilaku demonstratif, agresi, pemalu). Kesulitan komunikasi yang berasal dari kesalahan pengasuhan memainkan peran ambivalen dalam perkembangan anak sebagai komunikator. Di satu sisi, mereka membawa pengalaman yang merusak; menghambat evolusi sifat subjektif dan realisasi diri pada anak. Di sisi lain, mereka memobilisasi sumber daya pribadi; menstimulasi aktivitas tiruan, pengembangan diri dan kemandirian dalam komunikasi, mengungkapkan potensi komunikatif seorang anak. Jika anak-anak tidak dapat mengatasi kesulitan komunikasi sendiri dan menyelesaikan tugas komunikasikonteks sosial, perlu untuk memberikan bantuan psikologis yang disesuaikan, yang ditujukan untuk, pertama, membuat hubungan antara anak dan orang tua lebih harmonis dengan memperbaiki kesalahan pengasuhan ibu dan ayah. Kedua, penting untuk memotivasi anak-anak untuk mengatasi kesulitan komunikasi, mengungkapkan potensi mereka, mengajari mereka untuk mengendalikan dan mengekspresikan diri mereka dalam situasi komunikasi secara efektif dan mandiri.

20 A.G.Samokhlmvalova, Parenting Mistakes as a Factor in Communication Difficulties in Chlmildren. Procedia - Social and Behlmavioral Sciences, 233, 2016, hlm.123-127. hlmttps://doi.org/10.1016/J. SBSPRO.2016.10.164 
Berdasarkan pada paparan tersebut dapat diketahui bahwa kondisi proses komunikasi yang baik akan memaksimalkan kemampuan anak dengan kondisi sosial emosi yang baik. Sehingga pada saat anak berada pada usia sekolah dasar, mereka mampu memaksimalkan potensi yang dimiliki. Hal tersebut telah terbukti dalam penelitian Tarasova.Ada perbedaan yang signifikan secara statis oleh beberapa komponen komponen sosial emosi antara siswatingkat kedua dan keempat dalam tingkat kesadaran diri $(p=0,038)$ dan keterampilan sosial $(p=0,039)$. Meningkatkan kesadaran diri dari kelas kedua hingga keempat mungkin memiliki pembenaran dalam karakteristik usia sekolah dasar. Formasi baru yang penting dari tahap usia ini adalah munculnya harga diri, refleksi, kemampuan untuk menganalisis, perluasan pengetahuan tentang diri sendiri dan dunia yang memungkinkan anak-anak sekolah dasar untuk lebih memahami diri mereka sendiri dan untuk menilai kemampuan mereka, kekuatan dan kelemahan mereka, posisi mereka di kelas dan kelompok sosial lainnya lebih memadai. Pengembangan keterampilan sosial dari kelas kedua hingga keempat juga tampak logis karena fakta bahwa siswa kelas empat memperoleh pengalaman komunikasi yang lebih luas baik dengan teman sebaya dan orang dewasa dalam berbagai konteks sosial yang mungkin memerlukan keterampilan sosial yang beragam. Anak-anak di tahun ke-4 di sekolah biasanya termasuk dalam jumlah kelompok sosial yang lebih besar daripada siswa kelas dua, dan mereka menghadapi lebih banyak kesempatan untuk melatih keterampilan sosial mereka. Selain itu, siswa tahun keempat menemukan diri mereka di perbatasan masuk ke awal masa remaja, kegiatan utama yang tidak seperti anak kelas 2 dalam komunikasi antarpribadi daripada belajar. ${ }^{21}$ Dengan demikian, pengembangan keterampilan sosial, yang sangat penting untuk komunikasi yang sukses, mempersiapkan transisi dari usia sekolah dasar ke remaja untuk siswa kelas empat. Apa yang telah ditemukan sebagai hasil yang agak menarik adalah kurangnya perbedaan yang signifikan secara statis di tingkat umumkompetensi sosio-emosional antara murid kelas 2, 3 dan 4. Data mengakui asumsi bahwa kompetensi sosio-emosional, tingkat dan pola, lebih cenderung menjadi individu daripada fitur spesifik usia. Menurut output, diagnostik dan pengembangan kompetensi sosio-emosional mendapatkan arti khusus dalam bekerja dengan anak-anak. Jika tingkat kompetensi sosio-emosional tidak secara alami meningkat dalam komponen penting seperti empati, motivasi komunikatif, dan pengaturan diri dengan kematangan anak, kebutuhan akan pekerjaan yang bertujuan mengembangkan keterampilan defisit tetap diremehkan.

21 K. S.Tarasova, Development of Socio-emotional Competence in Primary Schlmool Chlmildren. Procedia - Social and Behlmavioral Sciences, 233, 2016, hlm. 128-132. hlmttps://doi.org/10.1016/J. SBSPRO.2016.10.166 


\section{PENUTUP}

Berdasarkan hasil temuan dapat disimpulkan bahwa orang tua memiliki pengaruh yang sangat besar terhadap pembentukan karakter sosial emosi anakanak. Hal tersebut dapat diketahui dari kedua indikator yang dikembangkan yaitu kecemasan dari ayah dan ibu sebesar 27,26) dan self-esteem dari ayah dan ibu $(27,27)$. Dengan demikian, orang tua harus memperhatikan aspek-aspek tersebut sebagai proses pembentukan anak dengan kepribadian yang baik. Karena manusia menjadi pemimpin dengan aspek persaingan intelijen yang baik dan harus ada dan diimbangi dengan aspek sosial emosional. Daya tahan mental yang kuat dicirikan oleh kemampuan individu untuk dapat menghadapi berbagai masalah dan menyelesaikannya dengan benar, dengan kata lain, seseorang harus mampu bertahan dan memiliki keberadaan hidup.Konsep pemikiran orang tua yang memberikan pendidikan yang layak untuk anak-anak mereka, mengharapkan sekolah sebagai sarana pendidikan kedua dapat menjadi alat untuk mengembangkanpotensi anak-anak, terutama sikap dasar dan kepribadian anak. Tetapi orang tua akan tetap menjalankan fungsinya sesuai dengan pola pemikiran dan budaya yang dibangun oleh keluarga dan masyarakat setempat.

Hasil kajian ini dapat dimanfaatkan sebagai pengembangan keilmuan untuk membangun konsep teori tentang pengembangan emosi sosial anak-anak. Selain itu, para ibu dan ayah bisa mulai merubah pola pendidikan anak-anak khususnya yang berkaitan dengan sosial dan emosi. Karena proses sosial dan emosi yang dialami semenjak usia dini akan mempengaruhi proses pendidikan dan kesuksesan di masa mendatang.

\section{DAFTAR PUSTAKA}

Abe, J. A., \& Izard, C. E. (1999). A longitudinal study of emotion expression and personality relations in early development. Journal of Personality and Social Psychology, 77, pp.566-577.

Bresly, G.M. (2010). Emotcionalnie osobennosti Formirovaniia Lichhnosti v Detstve: Norma I Otklonenie \{Emotional peculiarities of roaming the individual in childhood: norm and deviation\}. M:Pedagogika, p.246. \{in Russian\} 
Berk, L. (1997). Child development (4th ed.).Boston: Allyn \& BaconBerk, L.E. (2004). Awakening Children's Minds: How Parents and Teachers Can Make a Difference. Oxford University Press.

Cohen, D.H. \& Rudolph, M. (1977). Kindergarten and early schooling. New Jersey: Prentice-Hall Inc

Daradjat. Zakiah. (2012). Ilmu Pendidikan Islam. Jakarta: Bumi Aksara

Hurlock, E.B. (1978). Chiled Development. 6 ${ }^{\text {th }}$ Ed. Tokyo: Mc. Graw Hill. Inc., International Studend Ed.

Horny, K. (2008).Nevroticheskaia lichnost nashego vremeni. Samoanaliz. [Neurotic personality of our time. Introspection.]. M: Progress.

Karabanova O.A. (2005). Psikholiaa semeinikh otnoshenii I osnovy semeinigo konsyltirovaniia P Psychology of Human Intelligence $\left(2^{\text {nd }} e d\right)$. New York: Cambridge

Lisina, M.I. (2009). Formirovanie lichnosti rebenka v obshchenii [Forming personality of a child in communication]. St. Petesburg: Piter

Mansur. (2005). Pendidikan Anak Usia Dini dalam Islam Cet akan Ke-1. Yogyakarta : Pustaka Pelajar,

Moeslichatun. (1999). Metode Pengajaran di Taman Kanak-Kanak. Jakarta : Rineka Cipta

Nuraeni. (2006). Pengaruh Pola Asuh Orang Tua Terbadap Pembentukan Kepribadian Anak Taman Kanak-Kanak, Tugas Akbir Universitas Negeri Semarang. On line: http://digilib.unnes.ac.id/gsdl/collect/skripsi.1/tmp/2383.html (Accessed 25 Novermber 2018).

Santrock, John W. (2007). Perkembangan Anak Cetakan ke-7. Jakarta : Erlangga.

Sheffield Morris, A., Silk, J. S., Steinberg, L., Myers, S. S., \& Robinson, L. R. (2007). The role of the family context in the development of emotional regulation. Social Development, 16(2), pp 361-388.

Siegler, R., DeLoache, J., \& Eisenberg, N. (2011). How children develop. (3rd ed.). New York: Worth Publishers.

Sroufe, L. A. (2001). From infant attachment to promotion of adolescent autonomy: Prospective, longitudinal data on the role of parents in development. In J. G. Borkowski, S. L. Ramey \& M. Bristol-Power (Eds.), Parenting and the Child's World: Influences on Academic, Intellectual, and Social-emotional Development. Psychology Press. 
Saroinsong, Wulan Patria \& Cosmas Poluakan. (2017). Positive Contribution of Parenting and Socio -emotional Developmentin Children's Social Skills. International Journal of Humanities and Social Scienc 7(4),124-127

Samokhvalova, A. G. (2016). Parenting Mistakes as a Factor in Communication Difficulties in Children. Procedia - Social and Behavioral Sciences, 233, 123-127. https://doi.org/10.1016/J.SBSPRO.2016.10.164

Tarasova, K. S. (2016). Development of Socio-emotional Competence in Primary School Children. Procedia - Social and Behavioral Sciences, 233, 128-132. https:// doi.org/10.1016/J.SBSPRO.2016.10.166

Vasil'eva E.N. Nauchno-metodicheskie podkhody k otsenke rolevoy struktury sem'i //Nizhegorodskoe obrazovanie [Scientific and methodological approaches to the assessment of the role structure of the family //Education in Nizhny Novgorod]. 2013; 3: 85-91.

Volling, B., McElwain, N., Notaro, P., \& Herrera, C. (2002). Parents' emotional availability and infant emotional competence: Predictors of parent-infant attachment and emerging self-regulation. Journal of family psychology, 16, pp 447-465.

Vygotski, L. S. (1963). Learning and mental development at school age(J. Simon, Trans.). In B. Simon \& J. Simon (Eds.), Educational psychology in the U.S.S.R. (pp. 21-34). London: Routledge \& Kegan Paul

Vasilyeva, E. N., \& Shcherbakov, A. V. (2016). Parental Roles and Types of Parentings as Determinants of a Preschooler's Emotional and Personal Well-being. Procedia - Social and Behavioral Sciences, 233, 144-149. https://doi.org/10.1016/J. SBSPRO.2016.10.172

Zakharova, L. M., \& Silakova, M. M. (2016). The Child's Emotional Development as Basis for Cooperation between Kindergarten and Family. Procedia Social and Behavioral Sciences, 233, 318-321. https://doi.org/10.1016/J. SBSPRO.2016.10.143 
